\title{
An Alternative Power Supply System During Peak Loads Using Solar Cells
}

\author{
Zulhelmi, Zulfikar, Agus Mulyadi \\ Departement of Electrical and Computer Engineering, Syiah Kuala University, Indonesia
}

\begin{tabular}{l}
\hline \hline Article Info \\
\hline Article history: \\
Received Mar 10, 2018 \\
Revised Jul 4, 2018 \\
Accepted Aug 6, 2018 \\
\hline
\end{tabular}

\section{Keyword:}

Future energy

Green energy

Power back up

Renewable energy

Transfer adaptive

\begin{abstract}
Utilization of renewable energy becomes a necessity in the future due to the fossil energy supply continues to decline. In Indonesia, the use of electricity from renewable sources is minimal. The utilization of solar energy in Indonesia is still limited to remote areas or islands. The main problem of electricity in Indonesia, especially in the city of Banda Aceh, is the frequent occurrence of power outages from the state power plant (PLN), especially during peak load time (WBP). Outside of that time, electricity supply exceeds demand. This study aims to utilize solar energy to reduce the electricity consumption of PLN during WBP. The system is designed to divert the power supply from PLN to the solar power plant (PLTS). The results of a survey of $10 \mathrm{~A}$ (current limit) customers are used as a reference to calculate PLTS capacity. During WBP, PLTS supplies to the load, beyond that time, PLN will supply the load. The system is designed to store maximum energy beyond the WBP period into the battery, the source of energy is mainly from the PLTS and alternatively from the PLN when the PLTS can not supply the maximum power. Based on battery energy, the system diverts the load supply from PLN when the battery energy is below the recharge limit. In the case of 10 A customers, with the energy requirement during WBP of $4.3 \mathrm{kWh}$, it requires 12 solar panels (160 Watt maximum power) arranged in parallel. Thus, the system needs three batteries with 150 Ah capacity also assembled in parallel. The implementation results prove that the PLTS can store solar energy to the battery properly, the system also successfully divert the PLTS source to the load at the time of WBP and transfer back to the PLN source when the battery energy is less than the recharge limit.
\end{abstract}

Copyright (c) 2018 Institute of Advanced Engineering and Science. All rights reserved.

Corresponding Author:

Zulfikar,

Departement of Electrical and Computer Engineering,

Syiah Kuala University,

Jl Syech Abdul Rauf No. 7, Darussalam, 23111, Banda Aceh, Indonesia.

Email: zulfikarsafrina@unsyiah.ac.id

\section{INTRODUCTION}

Utilization of renewable energy becomes a necessity in the future due to the fossil energy supply continues to decline. When the energy is exhausted, it takes thousands of years to recycle. Research to look for renewable energy alternatives have been developed in recent decades. Several types of renewable energy such as sunlight, wind, ocean waves and others have begun to be exploited.

In Indonesia, the use of energy from renewable sources is relatively minimal. Only $16 \%$ of national electricity production in 2010 is derived from renewable energy sources [1]. Almost all of the total 16\% comes from water resources using hydropower. However, as electricity energy demand increase since 2016, the overall use of renewable energy has declined to just 6.8\% [2]. Therefore, increasing the use of electrical energy from renewable sources becomes imperative. Based on this, the Indonesian government has 
encouraged the private sectors to build a renewable energy power plants. However, a high investment and uncertainty of its usage regulations become a severe problem in the utilization of renewable energy in Indonesia.

One of the most easily utilized renewable energy at the moment is solar energy. The utilization of solar energy in Indonesia is still limited to remote areas or particular islands. The government is targeting the addition of solar power plant (PLTS) in remote areas to reach 346.5 MW by 2025 [3]. Meanwhile, the utilization of solar energy is minimal as long as the availability of power plant source from PLN. Lack of energy utilization is due to the high selling price of electricity from solar energy compared to PLN electricity.

The main problem of electricity in Banda Aceh is the frequent occurrence of power outages from the state power plant (PLN), especially during peak load time (WBP). The extinction is mainly due to insufficient electricity production especially during peak load (WBP). While outside peak load time (LWBP), the electricity generated far exceeds demand. Therefore, the government offers subsidies to the industry to reduce PLN's electricity usage during the WBP [4]. Another problem is the frequent occurrence of power outages due to disturbance both the plant and its distribution network. The second problem is still related indirectly to the first problem because of insufficient supply of electricity during the WBP. Power plants are forced to supply the maximum load during WBP. So it can reduce the reliability of the generator which resulted in frequent damage.

This research aims to utilize solar energy to reduce PLN electricity consumption during WBP. This study is very urgent to be carried out due to frequent power outages from PLN during WBP in Banda Aceh and other regions. The blackout was due to insufficient supply of electricity during peak loads, while power supply outside the WBP exceeded demand. After conducting this research, it is expected that it may be used as an alternative system of solar energy utilization during WBP. So that PLN's electricity usage will decrease during WBP. Thus, PLN power plants are not often damaged.

\section{BACKGROUND THEORY}

\subsection{Power Plants}

In Indonesia, the most massive company supplying electrical power is the Pembangkit Listrik Negara (PLN). The Indonesian government manages the power plants area. PLN provides electricity to almost all parts of Indonesia including remote areas and islands. Due to the vast and isolated territory of the oceans, the power grid in Indonesia is mostly unrelated to each other. Even on large islands such as Sumatra, there are three networks of electricity [5]. Therefore, most large production companies do not use electricity supplied by PLN. They build their power plants to meet the needs of plant operations.

Generally, the electricity produced by PLN is not sufficient. Besides, the total use of electricity is not evenly distributed over 24 hours. At certain hours, the need for electricity is not enough. Meanwhile, at other times electricity production is excessive. The disconnection between transmission lines exacerbates this. As a result, (for example) in an area lacking electricity during the night, while elsewhere, electricity production is excessive.

Pembangkit Listrik Tenaga Surya (PLTS) is a solar power plant that utilizes or converts solar energy into electrical energy. Power generation can be done in two ways, directly using photovoltaic and indirectly with energy concentration. Techniques that directly convert light energy into electrical energy go through the photoelectric effect [6]. The concentration of solar energy using a lens or mirror system combined with a tracking system to focus solar energy on a single point.

In Indonesia, the first largest PLTS with a capacity of $2 \times 1 \mathrm{MW}$ built in Bali, precisely in Karang Asem and Bangli. The Government invites anyone to rebuild and make it elsewhere because the PLTS is open source or not registered in copyright [7].

\subsection{Peak Load Times}

The period during the peak load of PLN electricity usage in Indonesia is known as Waktu Beban Puncak (WBP). In general, PLN has mapped that the peak load of electricity usage in Indonesia is from 18:00 to 22:00 [8]. However, it can vary depending on time and places. In areas where electricity is widely used by industry, WBP could happen during the day, while in other places WBP could occur at night. Then in certain situations, during the month of Ramadan, the WBP can shift up to 24:00.

Figure 1 shows the Java-Bali power consumption charge for 24 hours on March 2, 2011 [9]. From the curve can be seen that the peak use of electricity exceeds $18 \mathrm{GW}$ at around $8 \mathrm{pm}$. Meanwhile, the lowest PLN electricity usage burden occurred at around $3 \mathrm{pm}$ at $13 \mathrm{GW}$. The graph also shows that WBP uses electricity from $6 \mathrm{pm}$ to $10 \mathrm{pm}$ (18: 00-22: 00). There is a significant difference in power consumption between day and night or between WBP and outside WBP (LWBP). 


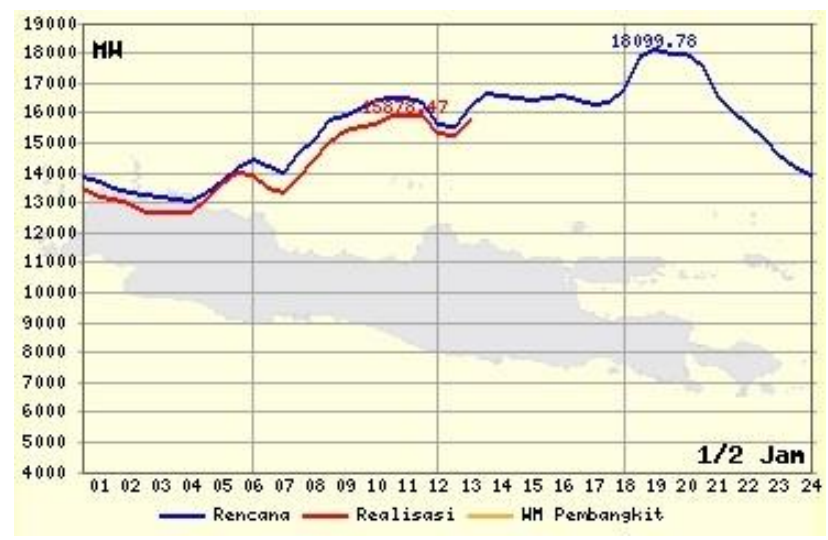

Figure 1. Jawa-Bali Power Consumption Curve [9]

The effect felt by customers during WBP is the drop in voltage to below 200 Volts. The magnitude of the voltage drop varies greatly depending on the region. It also directly depends on the amount of load on each distribution transformer. Some electrical appliances are not affected by the voltage drop. Nevertheless, some electrical devices that operate using electric motors will be affected.

\subsection{Backup Power System}

Some electrical appliances must be operated continuously for a specified period without interruption. Meanwhile, the electricity supply from PLN can be interrupted at any time either intentionally or not. Therefore, a backup electrical system is required to supply electricity for some time. Here is the backup power supply technology that is often used today.

\subsubsection{Automatic Transfer Switch}

An automatic transfer switch (ATS) is a device that automatically transfers power supply from a primary source (PLN) to a backup source when a failure or disconnection of supply from a primary source occurs. In the event of a failure in the primary power system, ATS calls the standby power source, so power remains available. ATS may also involve more long-term backup power systems, such as diesel generators, to run electrical equipment until the mains power from the primary source is recovered [10].

\subsubsection{Uninterruptible Power Supply}

An Uninterruptible Power Supply (UPS) is a device that keeps a device (e.g., a desktop computer) operating within a short time when the primary power source (PLN) is disconnected. These devices usually also protect the computer from shock currents. A UPS contains the battery used when it detects power loss from the main source [11-14]. Each UPS converts AC power to DC through a rectifier and converts it back with an inverter. Batteries or flywheels store energy for use in times of supply failure from primary sources.

Usually, a UPS is designed with a double-conversion model, line-interactive, and standby. This term has been used inconsistently, and manufacturers apply it differently. At least one UPS must allow one of the three modes [15]. The International Electro Technical Commission (IEC) adopted the technical description terminology at IEC Std. 62040. The UPS system with Voltage and Frequency Independent (VFI) is said to have double conversion since AC input is fixed to DC to hold the battery and drive the inverter. The inverters then provide stable AC power to run equipment such as computers [16]. Figure 2 shows one of the UPS scheme models.

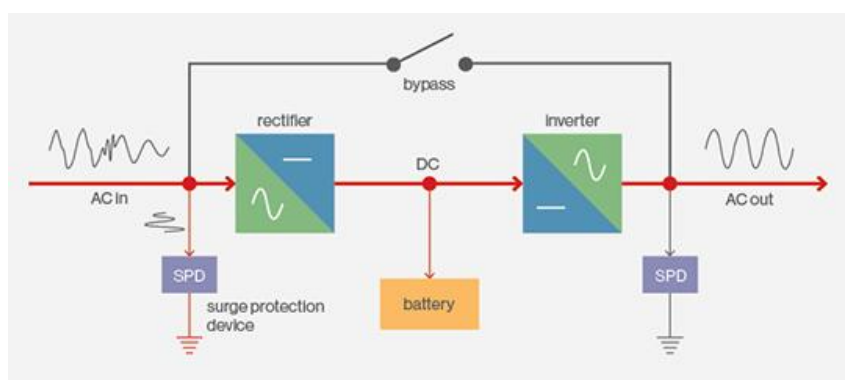

Figure 2. Internal circuit scheme of a UPS 


\subsection{Determine the Size of Solar Panels}

To determine the need or capacity of the required solar panels, it should be known some essential specification data. The initial data necessary to decide on panel size is like the solar panel voltage $\left(V_{s p}\right)$, minimum daily solar irradiation $\left(T_{m i n}\right)$, and energy requirement $\left(E_{d}\right)$ [17-19]. In the process of determining the size of solar panels, it is necessary to take into account some parameters referring to the previously mentioned initial data. The first step is to determine the average daily energy $\left(E_{r d}\right)$ required due to component imperfection. Some of the components that form the PLTS system that counts here are the charge controller, inverter, and battery. In practice, all parts are imperfect, or work efficiency does not reach $100 \%$. By involving the efficiency of the charge controller $\left(\eta_{c}\right)$, the inverter $\left(\eta_{i}\right)$ and battery $\left(\eta_{b}\right)$, the average daily energy requirement will be higher than the energy it wants, as indicated by (1).

$$
E_{r d}=\frac{E_{d}}{\eta_{b} \eta_{i} \eta_{c}}
$$

Then, the next step is determining average peak power $\left(P_{a v . p}\right)$. This power can be evaluated based on the minimum sun irradiation data $\left(T_{\min }\right)$ at the place PLTS to be established built PLTS. The value of solar irradiation is different every day of the year so that the reference is the minimum data to ensure the supply of energy at any time. Equation (2) is used to calculate average peak power.

$$
P_{a v \cdot p}=\frac{E_{r d}}{T_{\min }}
$$

Next, we can estimate the total current requirement $\left(I_{t}\right)$ by dividing the average peak power to the desired system voltage $\left(V_{s p}\right)$ according to the relation shown by equation (3).

$$
I_{t}=\frac{P_{a v \cdot p}}{V_{s p}}
$$

From that, then we can calculate the number of module requirements when connected in series $\left(N_{s}\right)$, i.e., by dividing the total dc voltage against the voltage on each module used $\left(V_{m}\right)$. This calculation is indicated by (4). The same is true for parallel modules, but this is obtained by dividing the total current $\left(I_{t}\right)$ against the module current $\left(I_{m}\right)$ used as seen in (5).

$$
\begin{aligned}
& N_{s}=\frac{V_{s p}}{V_{m}} \\
& N_{p}=\frac{I_{t}}{I_{m}}
\end{aligned}
$$

The total number of solar panel modules $\left(N_{t}\right)$ required forming an array of solar panels is established by multiplying the number of series modules by the number of parallel modules as seen in (6).

$$
N_{t}=N_{s} N_{p}
$$

\subsection{Determine Battery Capacity}

The recommended battery type for use on a PLTS system is a long-lasting battery type. So when repeatedly refilled (every day), the battery is expected to have a lifetime more than five years. The battery must also be large enough to be able to store the total energy required, so it is sufficient to operate at night, in rainy weather conditions, as well as overcast [20]. To determine the size of the battery, we first define the energy demand estimate $\left(E_{\text {est }}\right)$ and duration of energy consumption $\left(D_{\text {av.d }}\right)$ by using equation $(7)$ [21, 22].

$$
E_{\text {est }}=E_{d} D_{a v . d}
$$

After that, the battery should be able to accommodate more energy from the desired needs. This is to prevent the battery drained away. Most batteries will be tough to refill if the energy is completely depleted. To avoid this, safe energy storage $\left(E_{\text {safe }}\right)$ must take into account the deep of discharge (DOD) of a battery. Equation (8) shows the relationship between safe energy storage capacity, energy estimate and deep of charge $\left(D_{\text {disch }}\right)$ of a battery. 


$$
E_{\text {safe }}=\frac{E_{\text {est }}}{D_{\text {disch }}}
$$

Then the total capacity of the battery in ampere-hours $(\mathrm{Ah})\left(C_{t b}\right)$ is obtained by dividing safe energy storage with the used battery voltage $\left(V_{b}\right)$ if using more than one battery using equation (9). So the total number of batteries $\left(N_{t b}\right)$ can be estimated by equation (10), by dividing the total battery capacity by capacity per battery.

$$
\begin{aligned}
C_{t b} & =\frac{E_{\text {safe }}}{V_{b}} \\
N_{t b} & =\frac{C_{t b}}{C_{b}}
\end{aligned}
$$

The number of series-connected battery requirements $\left(N_{s b}\right)$ can be obtained by dividing the DC voltage of the solar panel against voltage per battery if they are not the same as shown in (10). Similarly, the number of batteries in parallel can be obtained by dividing the total amount of batteries against the number of batteries arranged in series according to equation (11).

$$
\begin{aligned}
& N_{s b}=\frac{V_{D c}}{V_{b}} \\
& N_{P b}=\frac{N_{t b}}{N_{s b}}
\end{aligned}
$$

\section{SYSTEM DESIGN}

Due to various electrical problems in Indonesia (may also occur in other countries), it is necessary to design a system that diverts the use of the main electricity supply (PLN) to the PLTS power supply automatically. This process of diversion will occur within the range of peak electrical energy usage times in a given place. Figure 3 shows the basic design of power supply diversion system from PLN to PLTS. In general, the system requires a circuit that serves to divert the power supply from the PLN source to the PLTS source. The source redirection system is designed to work automatically only during peak loads.

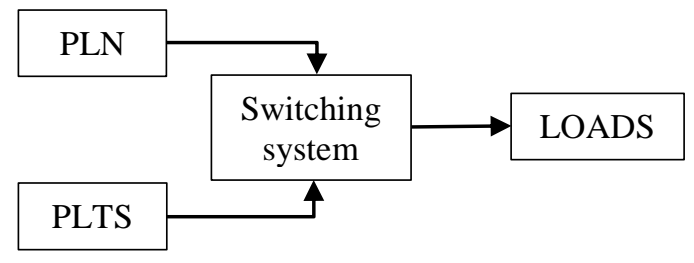

Figure 3. Design of Solar Energy Utilization System During Peak Load

Figure 4 shows the detailed design of solar energy utilization system during peak load of PLN electricity usage. The designed system diverts the use of PLN electricity to the PLTS during peak loads. In general, the Controller always reads the time provided by the System Timer. When entering the WBP, the command is sent to the switching circuit. The circuit will divert the energy supply from PLN to the inverter (battery). Furthermore, if it is entering LWBP, then the command signal to the switching circuit is stopped. This causes the switching of the power supply back to PLN. Here are some of the components or sequences needed to build the system. 1) Controller, it functions to manage all system processes. This main device reacts mainly base on time provided by timing system and battery energy which is monitored using a sensor. 2) Switching circuit, it serves to divert power supply from PLN to PLTS through an inverter. 3) Charging circuit, it serves to store energy absorbed by the solar panel into the battery and may be utilized to store PLN electricity into the battery. 4) The timing system, used as a reference for determining WBP and LWBP. 5) Display, it utilized to display real-time system condition and to change the time if needed. 6) Battery sensor, 
it used to detect the energy capacity stored in the battery. 7) Inverter, used to convert DC voltage (battery) into AC voltage; 8) Solar panel, serves to capture energy from sunlight.

Figure 5 shows the flowchart of how the system operates. The system starts by defining the threetime zones LWBP, approaching the WBP and WBP. After the zone definition process is complete, next is to start counting the time. This timing process is based on the information supplied by the Timing system (see Figure 4). Then the system will check the current time to decide which time zone is. The first decision to be made is currently in the LWBP zone or not. If the LWBP zone, then PLTS connected to the battery (the battery in charge with PLTS). At the same time, the system also links the PLN source to the load.

If that time does not include LWBP, the system determines the second decision. The second verdict checks whether the system includes ahead of the WBP or not. If at that time is the time leading up to WBP, then the system will check the condition of the battery. If the battery is not full (e.g., not fully charged by PLTS because the previous situation is cloudy), then the battery is charged to full with PLN sources. The timezone ahead of WBP is designed to make the system more flexible. The amount of energy stored during LWBP may not be sufficient for use during WBP or due to other factors that cause the battery is not full.

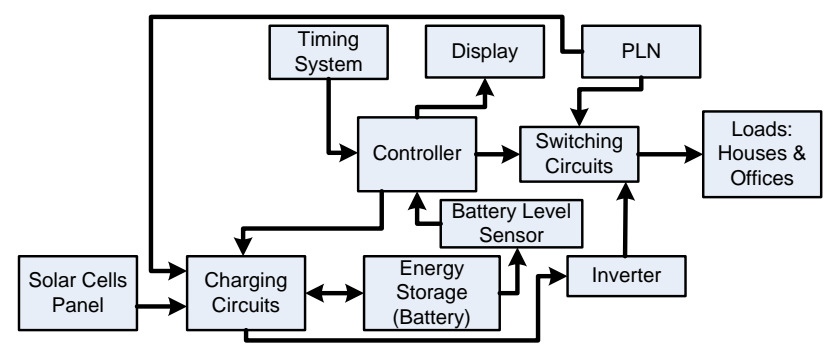

Figure 4. Design of solar energy utilization system during peak load

Furthermore, if the current time includes the WBP zone, then the system will connect the PLTS (battery via inverter) to the load. This will continue until the end of the WBP zone. If the battery energy is drained to the extent of recharging before the end of the WBP zone, then the system will switch the load connection back to the PLN supply. This process of redirection is to prevent the draining of battery energy below the deep of charge. Therefore, the system is also equipped with sensors to detect battery energy. Furthermore, when the WBP zone ends, the system will be restarted from the beginning. It goes on and on every day unless the system is disabled.

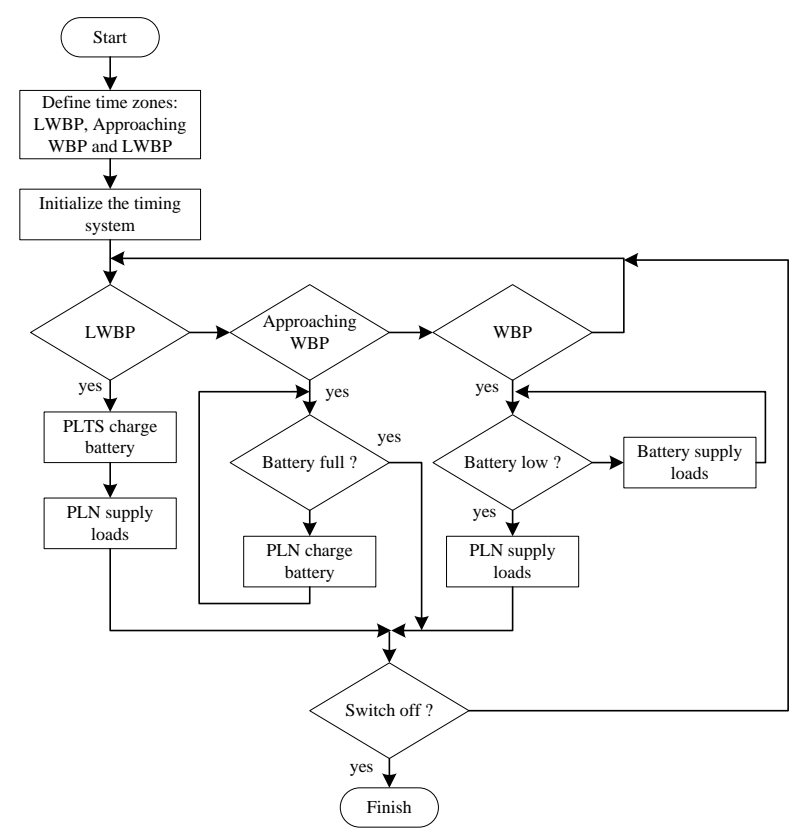




\section{RESULTS AND DISCUSSIONS}

Figure 5. Flowchart of Solar Energy Supply System During WBP

The design of alternative solar energy utilization systems during the WBP along with the flowchart of the system workflow has been successfully realized. Next is the process of estimating the capacity of the PLTS under the needs of the home or office. The system is designed to be installed only in a home or office. If installed in another house, it must be adjusted to the estimated needs of other homes. To get an idea of the expected electricity demand during the WBP, we have surveyed homes. The survey conducted on electric customers with a maximum current load of $10 \mathrm{~A}$. In Indonesia, each customer is given maximum current limits that can be used. This restriction relates to the price of using electricity per $\mathrm{kWh}$.

The survey results show that customers who use electricity with a $10 \mathrm{~A}$ limit, the average power consumed during WBP (18:00 to $22: 00$ ) are $4.3 \mathrm{kWh}$ or about $40 \%$ of total electricity consumption per day. This data will be used as a reference to design the capacity of the built-in PLTS and its control system. Table 1 shows the approximate results of solar panel needs. Before determining the needs of solar panels, some data must be available, such as energy requirements, solar panel specifications, system voltage, solar irradiation, and efficiency of all devices used.

The system is designed using Solarland SLP160S-12 monocrystalline solar panels. The solar panel has a maximum power supply capability of $160 \mathrm{~W}$, voltage $V_{m}=12 \mathrm{~V}$ and maximum current with load $I_{m}=$ $8.8 \mathrm{~A}$ [23]. Then, we assume that the efficiency of inverter $\left(\eta_{i}\right)=0.90$, battery $\left(\eta_{b}\right)=0.85$ and charge controller $\left(\eta_{c}\right)=0.95$ [24]. The sun irradiation for Banda Aceh (latitude $=5.5483$ and altitude $=95.3238$ ) throughout the year varies daily from 4.66 to 5.79. Therefore, we consider that $T_{\min }$ is 4.66 [25].

Table 1. Calculation of Solar Panel Capacity Requirements

\begin{tabular}{|c|c|c|}
\hline \multicolumn{3}{|l|}{ Required Information: } \\
\hline \multicolumn{3}{|c|}{$\begin{array}{l}\text { Solar modules data: Solarland SLP160S-12 Monocrystalline: } V_{m}=12 \mathrm{~V} \\
\text { System voltage }\left(V_{s p}\right)=12 \mathrm{~V} \\
\text { System voltage }\left(V_{s p}\right)=12 \mathrm{~V} \\
\text { Average sun hours for Banda Aceh }\left(T_{\text {min }}\right)=4.66 \\
\text { Average energy demand }\left(E_{d}\right)=4,300 \text { Watt-hours } \\
\text { Battery efficiency }\left(\eta_{\mathrm{b}}\right)=0.85 \\
\text { Inverter efficiency }\left(\eta_{\mathrm{i}}\right)=0.90 \\
\text { Charge controller efficiency }\left(\eta_{\mathrm{c}}\right)=0.95\end{array}$} \\
\hline Calculating Parameters & Formulas & Result values \\
\hline Required energy demand $\left(E_{r d}\right)$ & $E_{r d}=\frac{E_{d}}{\eta_{b} \eta_{i} \eta_{c}}$ & 5,917 Watt-hours \\
\hline Average peak power $\left(P_{a v \cdot p}\right)$ & $P_{a v \cdot p}=\frac{E_{r d}}{T_{\min }}$ & 1,270 Watt \\
\hline Total DC current $\left(I_{t}\right)$ & $I_{t}=\frac{P_{a v \cdot p}}{V_{s p}}$ & $105.8 \mathrm{~A}$ \\
\hline Number of series modules $\left(N_{s}\right)$ & $N_{s}=\frac{V_{s p}}{V_{m}}$ & 1 \\
\hline Number of parallel modules $\left(N_{p}\right)$ & $N_{p}=\frac{I_{t}}{I_{m}}$ & 12 \\
\hline Total number of modules $\left(N_{t}\right)$ & $N_{t}=N_{s} N_{p}$ & 12 \\
\hline
\end{tabular}

Based on the calculations as shown in Table 1, it takes at least 12 solar panels arranged in parallel. The number and order of panels will be different if using other types of solar panels. The need for the number of panels also depends on the system voltage being designed. Furthermore, the system voltage $(12 \mathrm{~V})$ and the total current $\left(I_{t}\right)$ obtained will be used as a reference for determining charge controller, inverter, and battery specifications. In this study, we did not design the charge controller capacity. Meanwhile, the decision of the inverter depends on the wishes of each customer against the minimum power constraint is the same as the power supplied by the PLN. Where, for a customer with a $10 \mathrm{~A}$ load, his maximum power limit is $2200 \mathrm{VA}$.

Next is to determine the capacity of the energy storage battery from the solar panel. Table 2 shows the approximate results of battery capacity used in solar energy storage. Before deciding battery capacity, some data must be available, such as energy requirements, system voltage, and the number of days of use. The system uses Luminous SMF $12 \mathrm{~V} / 150 \mathrm{AH}$ battery. The battery has a maximum energy saving capability $C_{b}=150 \mathrm{Ah}$ and a voltage $V_{b}=12 \mathrm{~V}$ [26]. Then, we assume that the deep discharge of the battery is $D_{\text {disch }}=$ $80 \%$ [27]. This means that the battery can be used until the remaining $20 \%$ energy, then the battery must be recharged. The system designed to supply energy during WBP every day. The stored energy will be used up during the WBP and even if there is only a small amount left. Exceptions if in some instances energy is not 
used because the occupants are not at home during WBP. Therefore the number of days usage is $D_{a v . d}=1$ day.

Based on the calculations as shown in Table 2, it takes at least three pieces of batteries arranged in parallel. The number and order of batteries will be different if using other battery types. The number of batteries also depends on the system voltage being designed.

Table 2. Estimated Battery Capacity

\begin{tabular}{|c|c|c|}
\hline \multicolumn{3}{|l|}{ Required data: } \\
\hline \multicolumn{3}{|c|}{$\begin{array}{l}\text { Number of days autonomy }\left(D_{a v, d}\right)=1 \text { day } \\
\text { Battery: Luminous SMF } 12 \mathrm{~V} / 150 \mathrm{AH}, C_{b}=150 \mathrm{Ah}, V_{b}=12 \mathrm{~V}, D_{d i c h b}=80 \%\end{array}$} \\
\hline Calculating Parameters & Formulas & Result values \\
\hline Estimate energy storage $\left(E_{\text {est }}\right)$ & $E_{\text {est }}=E_{d} D_{a v \cdot d}$ & 4,300 Watt-hours \\
\hline Safe energy storage $\left(E_{\text {safe }}\right)$ & $E_{\text {safe }}=\frac{E_{e s t}}{D_{\text {disch }}}$ & 5,375 Watt-hours \\
\hline Total capacity of battery $\left(C_{t b}\right)$ & $C_{t b}=\frac{E_{s a f e}}{V_{b}}$ & $448 \mathrm{Ah}$ \\
\hline Total number of batteries $\left(N_{t b}\right)$ & $N_{t b}=\frac{C_{t b}}{C_{b}}$ & 3 \\
\hline Number of series batteries $\left(N_{s b}\right)$ & $N_{s b}=\frac{V_{D c}}{V_{b}}$ & 1 \\
\hline Number of parallel batteries $\left(N_{p b}\right)$ & $N_{P b}=\frac{N_{t b}}{N_{s b}}$ & 3 \\
\hline
\end{tabular}

The next step is the realization of an alternative supply system using a solar cell. The control system uses the Arduino Uno board. The board has been programmed according to the flowchart as shown in Figure 5. To simplify testing procedure or implementation process, some processes have been conditioned or simulated according to the actual conditions when the system is installed at home. Figure 6(a) shows the realization circuit of the system. In the picture seen components such as inverters, charge controllers, Arduino boards, several relays, battery sensors, RTC, and connecting cables. Meanwhile, Figure 6(b) shows the calibration and measurement process to adjust the parameters to the desired conditions.

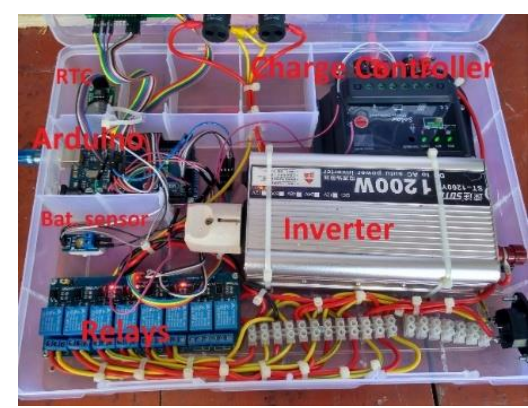

(a)

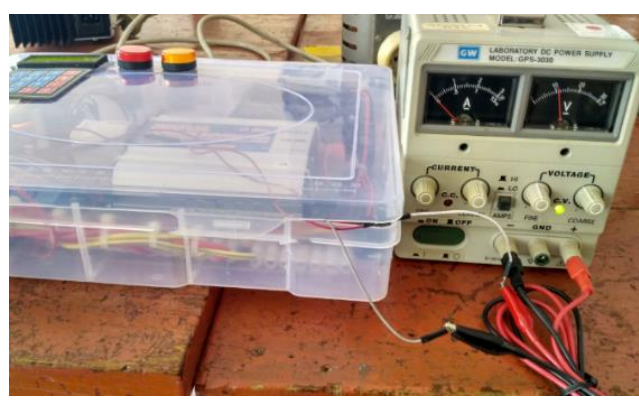

(b)

Figure 6. Realization of Alternative Power Supply Systems During WBP, (a) Components of Systems, (b) Testing and Calibration Processes

As mentioned earlier of switching supply from PLN to PLTS and vice versa is based on the zone and battery energy, it is necessary to monitor the energy of the battery anytime. Battery energy sensors are used to measure energy based on measured voltage. Theoretically, there is no standardization of voltage values related to battery energy. However, the voltage typically ranges from $11 \mathrm{~V}-13 \mathrm{~V}$ [21]. Therefore, we measure the battery characteristics to determine battery energy. The measurement results are referred parameters for Arduino board programming and to facilitate the determination of whether the battery is full, not full or under deep of charge.

The system has been programmed to recognize three time zones by providing restrictions such as WBP time zone from 18:00 to 22:00, the time zone ahead of WBP is from 17:00 to 18:00, and outside of the zone is LWBP. Figure 7 shows the various connections between PLN and PLTS supply to loads related to battery energy and time (WBP and LWBP). Figure 7(a) shows the morning when LWBP (08:49 am). At that 
time, the supply to the load from the PLN (indicated on the LCD and the turning on indicator). Figure 7(b) shows the afternoon (18:24 or 06:24 pm) when it enters the WBP zone. The image also shows that the supply to the load is connected to the PLTS, this is also indicated by the ignition of the PLTS connection light. Meanwhile, Figure 7(c) shows the afternoon conditions (18:00:37) when it enters the WBP zone, the load connection is still from the PLN supply. This happens because the battery energy is below the $30 \%$ limit (LOWBAT). It has been programmed that if the battery energy is below $30 \%$, then the battery is considered to be discharged and will not be connected to the load. It should be noted that the conditions as shown in the last will never happen because the battery has been previously charged with a solar cell or PLN. The conditions in Figure 7 (c) are engineered to show (test) system performance.

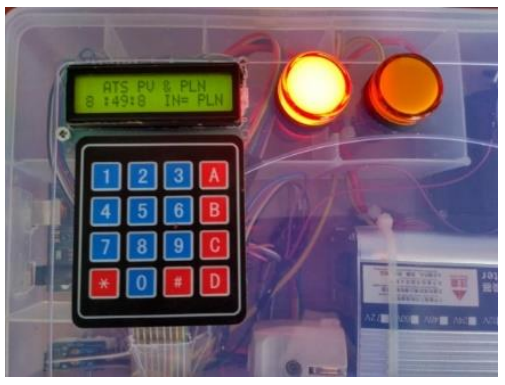

(a)

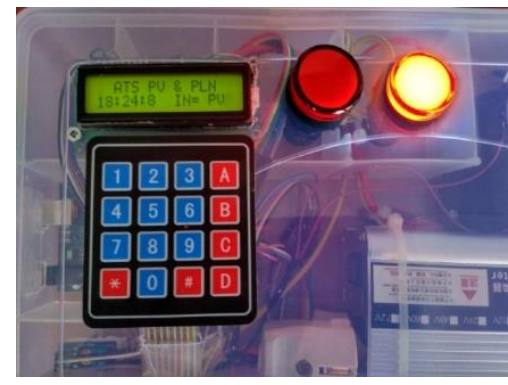

(b)

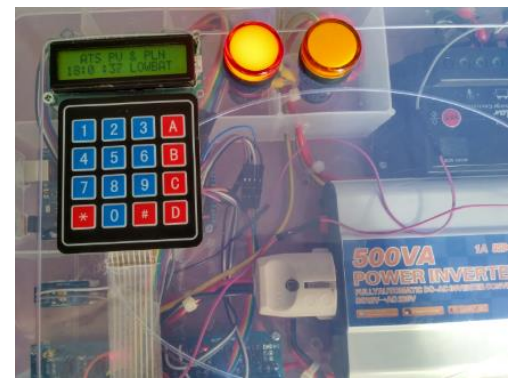

(c)

Figure 7. The Current Condition of the System, (a) LWBP Time Zone, (b) Supply from PLTS (WBP), (c) Supply from PLN (WBP)

\section{CONCLUSION}

From the results of this study, it can be concluded that the alternative system of electricity supply during WBP using PLTS has been successfully designed and realized. The results of a customer survey with a 10 A current limit indicate that the consumption of electrical energy during WBP (18:00 - 22:00) in Banda Aceh is $4.3 \mathrm{kWh}$. Then the survey results are used as a reference to calculate the number of solar panels. The need for solar panels (maximum power of 160 Watt and several other assumptions) is 12 pieces arranged in parallel. Furthermore, the system requires a battery capable of storing energy up to 448 Ah or using three batteries with a capacity of $150 \mathrm{Ah}$ (coupled in parallel). The implementation results show that the system is working properly. Battery energy is determined based on manual voltage measurement results. The battery needs to be recharged if its capacity is less than $30 \%$. The system can divert the PLN power supply to the PLTS during peak load. The system is also capable of detecting and monitoring battery energy.

The system can also be used to drain current beyond the maximum limit $(10 \mathrm{~A})$ for some time. However, the system must be equipped with an inverter capable of flowing alternating current higher than 10 A. The determination of the WBP zone depends on electricity consumption. There may be places where the WBP zone is not at night but in the daytime. Further research needs to be done, especially the realization of real systems installed in a home or offices. Monitoring takes a long time to get parameters so that system performance can be improved.

\section{REFERENCES}

[1] A. V. Deshmukh, Microcontrollers: theory and applications: Tata McGraw-Hill Education, 2005.

[2] A. Chrisbiyanto. (June 11, 2016, February 22). Penggunaan Energi Terbarukan di Indonesia Hanya 6,8\%. Available: https://ekbis.sindonews.com/read/1115774/34/penggunaan-energi-terbarukan-di-indonesia-hanya-681465596213

[3] Tim Komunikasi ESDM. (June 19, 2012, February 22). Matahari Untuk PLTS di Indonesia. Available: https://www.esdm.go.id/id/media-center/arsip-berita/matahari-untuk-plts-di-indonesia

[4] N. I. Gunarba. (April 5, 2011, February 22). PLN Beri Diskon Hingga 50\% bagi Pelanggan Industri dan Bisnis Beban Puncak Jawa-Bali 18.500 MW. Available: http://www.neraca.co.id/article/1649/pln-beri-diskon-hingga-50bagi-pelanggan-industri-dan-bisnis-beban-puncak-jawa-bali-18500-mw

[5] Tim Komunikasi ESDM. (October 10, 2014, February 22). Proyek Transmisi Sumatera Dan Transmisi SumateraJawa Dicanangkan. Available: https://www.esdm.go.id/en/media-center/news-archives/proyek-transmisi-sumateradan-transmisi-sumatera-jawa-dicanangkan

[6] P. Gevorkian, Solar power in building design: the engineer's complete design resource, 2008. 
[7] Indonesia Contained Energy, "Buku Panduan Energi yang Terbarukan," Kementerian Dalam Negeri. Jakarta, 2011.

[8] O. Ramlee. (March 7, 2016, February 22). Pemakaian Listrik lebih Besar di bawah jam 10 malam. Available: https://listrikdirumah.com/2016/03/07/pemakaian-listrik-lebih-besar-di-bawah-jam-10-malam/

[9] Watergius. (March 2, 2011, February 22). Kurva beban dan alasan memiliki beragam pembangkit. Available: https://watergius.wordpress.com/2011/03/02/kurva-beban-dan-alasan-memiliki-beragam-pembangkit/

[10] B. Andre and P. Reymond, Automatic Transfer System Generic Book: Schneider Electric, 2016.

[11] M. Courtemanche. (April 2015, February 22). Uninterruptible power supply (UPS). Available: https://searchdatacenter.techtarget.com/definition/uninterruptible-power-supply

[12] B. Berbaoui, S. Dib, and R. Dehini, "Grid-connected Photovoltaic Power Systems and Power Quality Improvement Based on Active Power Filter," Indonesian Journal of Electrical Engineering and Computer Science, vol. 12, pp. 5861-5868, 2014.

[13] S. Ganesh, C. Ghosh, R. Kokilasree, and M. Nandhakumar, "DC UPS for Critical Loads," International Journal of Electrical and Computer Engineering (IJECE), vol. 5, pp. 231-242, 2015.

[14] C. Sharma and A. Jain, "Entrepreneurship through Start-ups in hill areas using photovoltaic systems," Bulletin of Electrical Engineering and Informatics, vol. 6, pp. 105-121, 2017.

[15] N. Rasmussen, "The different types of UPS systems," White paper, pp. 1-10, 2003.

[16] J. Doucet, D. Eggleston, and J. Shaw, "DC/AC Pure Sine Wave Inverter," 2007.

[17] M. Boxwell, "Solar Electricity Handbook—2015 Edition: A Simple, Practical Guide to Solar Energy—Designing and Installing Solar PV Systems," Coventry: Greenstream Publishing, 2015.

[18] C. J. Roos, "Solar electric system design, operation and installation: an overview for builders in the US Pacific Northwest," 2009.

[19] State Renewable Energy, Solar Power: The Complete Guide to Understanding Solar Electricity, 2014.

[20] D. J. Fricke, "The World of Batteries-Functions, Systems, Disposal," GRS Batteries, Hamburg, Germany, 2007.

[21] T. P. Crompton, Battery reference book: Elsevier, 2000.

[22] A123 Energy Solutions, "Battery Pack Design, Validation, and Assembly Guide using A123 Systems AMP20m1HD-A Nanophosphate Cells," 2014.

[23] Solarland, "SLP160S-12 High Efficiency Monocrystalline PV Module," 2016.

[24] Anonymous. (2012, February 22). Choosing and Sizing Batteries, Charge Controllers and Inverters for Your OffGrid Solar Energy System. Available: https://solartown.com/learning/solar-panels/choosing-and-sizing-batteriescharge-controllers-and-inverters-for-your-off-grid-solar-energy-system/

[25] Paul W. Stackhouse. (March 28, 2008, February 22). Surface meteorology and Solar Energy: A renewable energy resource web site. Available: https://eosweb.larc.nasa.gov/cgibin/sse/retscreen.cgi?email=rets\%40nrcan.gc.ca\&step=1\&lat=5.5483\&lon=95.3238\&submit=Submit

[26] Anonymous. (February 22). Solar Battery - LPTT 12150H. Available: https://www.luminousindia.com/lptt-12120h1243.html

[27] W.-Y. Chang, "The state of charge estimating methods for battery: A review," ISRN Applied Mathematics, vol. 2013, 2013.

\section{BIOGRAPHIES OF AUTHORS}
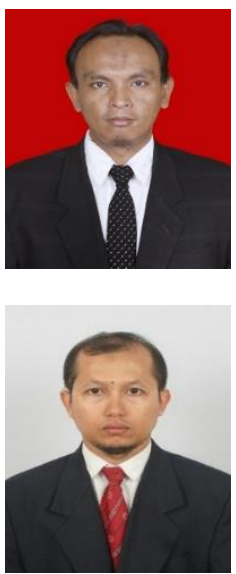

Zulhelmi, he was born in 1979 in Gigieng Simpang Tiga, which is located in Pidie District Aceh. He received the B.E. degree from Syiah Kuala University, Banda Aceh, Indonesia in 2003, and the M.Sc degrees in electrical engineering from King Saud University, Riyadh Saudi Arabia in 2013. He has been a Lecturer at Electrical Engineering department, Syiah Kuala University since 2003. Since 2017, he has been appointed as head of Electrical Engineering Department. His research interests include Electronic design, FPGAs architecture design, FPGAs implementation, VLSI architecture design, VLSI implementation and computer arithmetic.

Zulfikar, he was born in Beureunuen, Aceh, Indonesia, in 1975. He received his B.E. degree in Electrical Engineering from North Sumatera University, Medan, Indonesia, the M. Sc. Degree in Electrical Engineering from King Saud University, Riyadh, Saudi Arabia, in 1999 and 2011, respectively. Currently, he is studying the Ph.D. program at the University of Malaya, Malaysia. He joined as teaching staff in the Department of Electronics at Politeknik Caltex Riau, Pekanbaru, Indonesia in 2003. He served as head of Industrial Control Laboratory, Politeknik Caltex Riau from 2003 to 2006. In 2006, he joined the Electrical Engineering Department, Syiah Kuala University. He has been appointed as head of Digital Laboratory for two successive years. His current research interests include VLSI design, System on Chips (SoC) and System for gathering renewable energy. 


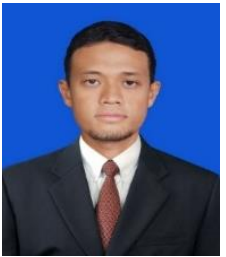

Agus Mulyadi, he was born in Banda Aceh in 1991. He obtained his associate's degree (A.Md) at the department of electronics engineering of mathematics and natural sciences faculty (MIPA), and the bachelor's degree in electrical and computer engineering of engineering faculty of Syiah Kuala University in 2013 and 2018, respectively. In the period 2010 to 2011, he had been an assistant at the laboratory of electronics and optoelectronics while still studying at the faculty of maths and natural sciences. 